\title{
INFLUENCE OF HOME BLEACHING AGENTS ON SURFACE TOPOGRAPHY OF TOOTH COLORED RESTORATIVE MATERIALS
}

\author{
Hala Ahmed Abd El-Moneim*, Inas Mohy El-Din** and Inas Elghandour***
}

\begin{abstract}
Aim: This study evaluated the influence of bleaching agents on the surface roughness and topography of two resin based restorative materials; Tetric Ceram resin composite and F2000 compomer after different time intervals.

Materials and Method: A total of 180 specimens were prepared from both restorative materials; 90 specimens from Tetric Ceram and the other 90 from F2000. Surface roughness was measured before any treatment. Specimens were stored in artificial saliva [no treatment], or bleached with $15 \%$ carbamide peroxide or 35\% carbamide peroxide for different times; 24 hours, one week or one month. Surface roughness was again measured and the difference from pretreatment measurements was statistically analyzed. The morphological changes were evaluated using Environmental Scanning Electron Microscope.

Results: Bleaching using 15\%carbamide peroxide, and 35\%carbamide peroxide increased significantly the surface roughness of Tetric ceram and F2000 compared to control group after hours, one week. After one month, the difference was statistically non-significant. Regarding storage times, the surface roughness increased significantly from 24 hours to one week to one month. Comparing both materials, surface roughness values were statistically non-significant following different treatments at different times. SEM examination revealed that bleaching increases surface roughness for Tetric Ceram and F2000 especially with increased time.
\end{abstract}

Conclusion: Home bleaching agents enhanced the changes in surface roughness and topography of hybrid resin composite and compomer.

\section{INTRODUCTION}

Aesthetic dentistry is a rapidly growing branch in the era of cosmetic dentistry. Tooth whitening is requested by many patients. Teeth discoloration might be due to intrinsic or extrinsic stains or combination of them. Intrinsic stains might be due to developmental disorders or drug administration during enamel and dentine formation. Extrinsic stains are caused by some types of food, drinks or smoking. Stains could be removed either by scaling,

\footnotetext{
* Researcher, Operative Dentistry Department, Faculty of Dentistry, Cairo University, Egypt

** Professor of Operative Dentistry, Faculty of Dentistry, Cairo University, Egypt

*** Associate Professor of Operative Dentistry, Faculty of Dentistry, Cairo University, Egypt
} 
polishing, vital or non-vital bleaching, micro abrasion, laminates or full coverage crown ${ }^{(1)}$.

Bleaching is a whitening process using an oxidizing agent such as hydrogen peroxide or carbamide peroxide. It is either vital bleaching for teeth with extrinsic stains or non-vital bleaching for endodontically treated teeth. Vital bleaching is performed in office under the dentist supervision using a high concentration of oxidizing agents as peroxides and it could be further activated by light or heat. Another mean of vital bleaching is at home bleaching first described by Haywood and Heymann (2). It is performed using low concentrations of peroxide bleaching agents. It is applied by the patient himself as paint on, night custom-fitted preserve or as strips. Reports have shown high degree of patient interest, excellent clinical effectiveness and comparable or lower prevalence of tooth sensitivity compared to chair side methods ${ }^{(3)}{ }^{(4)}{ }^{(5)}$. At home bleaching has some advantages as its ease of manipulation, lower cost and its availability to the patients. However, the availability of several home bleaching agents and increased use of them by patients at home showed some adverse effects such as tooth sensitivity, mucosal irritation and tooth substructure alteration. They may alter the surface roughness, micro-morphology and hardness of the applied restoratives ${ }^{(6)}$. This subsequently will lead to degradation of restorative materials.

The increase in surface roughness gives a dull appearance to the restoration, enhances plaque adherence and bacterial adhesion to the restoration surface. This might encourage the recurrence of decay and attracts the stains from food and beverages to the restoration surface leading to deranged esthetics. Resin based restorative materials have been reported to be adversely affected by bleaching agents' applications (7) (8) (9). Changes in surface roughness, porosity and hardness of resin composites and compomers after at home bleaching were reported.
The great number of at home bleaching products and the different methods employed in the current researches beside the presence of many interacting variables led to controversial results. Subsequently an understanding of the actual effect of at home bleaching agents on restorative materials is greatly needed. Therefore, this study was conducted to study the influence of two different concentrations of home bleaching agents; $15 \%$ and $35 \%$ carbamide peroxide on the surface roughness and micro morphological changes of two esthetic restorative materials namely, hybrid resin composite and polyacid modified resin composite (compomer) after different time intervals 24 hours, one week and one month.

\section{MATERIALS AND METHODS}

\section{Materials and study design:}

Two esthetic restorative materials were selected for this study, namely Tetric Ceram resin composite and F2000 compomer restorative materials. A3.5 shade was chosen for both materials. The materials were stored in a refrigerator to avoid light exposure and subsequently premature polymerization following the manufacturer's instructions. Two bleaching agents were used in this study. Opalescence PF $15 \%$ and 35\%carbamide peroxide home bleaching agent [table 1]. A total of 180 specimens was prepared from the tested restorative materials. Ninety specimens were prepared from Tetric Ceram resin composite and the other ninety were prepared from F2000 compomer. The 90 specimens were divided into three equal subgroups of 30 specimens each according to treatment received: first subgroup was left untreated to act as control group; second subgroup was treated with Opalescence PF 15\% carbamide peroxide and third subgroup was treated with Opalescence PF 35\% carbamide peroxide. Each subgroup was further divided into three equal divisions of 10 specimens each according to the test periods either 24 hours, one week, or one month. 
TABLE (1) Description of materials

\begin{tabular}{|c|c|c|}
\hline Material & Chemical composition & Manufacturer \\
\hline Tetric Ceram & $\begin{array}{l}\text { Bis-GMA (Bis-phenolglycidyl-methacrylate), urethane dimethacrylate and } \\
\text { TEGDMA (triethylene glycol dimethacrylate) } 20.2 \% \text { weight. The inorganic } \\
\text { fillers comprise barium glass, Ba-Al-fluorosilicate glass, highly dispersed } \\
\text { silicon dioxide, and spheroid mixed oxide. The total content of inorganic } \\
\text { fillers is } 79 \% \text { weight or } 60 \% \text { volume. The particle size is } 0.04-3.0 \mu \mathrm{m}\end{array}$ & $\begin{array}{l}\text { Ivoclar Vivadent, } \\
\text { Schaan/ Liechtenstein }\end{array}$ \\
\hline F2000 & $\begin{array}{l}\text { Fluroalumino silicate, Colloidal silica, Dimethyle functional oligomer } \\
\text { derived from citric acid, high molecular weight hydrophilic polymer, } \\
\text { Glyceryl dimethacrylate, and photo initiator }\end{array}$ & $\begin{array}{l}\text { 3M dent products, St. } \\
\text { Paul, MN, USA }\end{array}$ \\
\hline $\begin{array}{l}\text { Opalescence PF } 15 \% \\
\text { carbamide peroxide }\end{array}$ & $\begin{array}{l}0.5 \% \text { potassium nitrate, } 0.11 \% \text { weight }(1100 \mathrm{ppm}) \text { fluoride ion, } 15 \% \\
\text { carbamide peroxide and } 0.25 \% \text { sodium fluoride. Its } \mathrm{pH} \text { is } 6.5\end{array}$ & $\begin{array}{l}\text { Ultra-dent Products, } \\
\text { Utah, USA }\end{array}$ \\
\hline $\begin{array}{l}\text { Opalescence PF } 35 \% \\
\text { carbamide peroxide }\end{array}$ & $\begin{array}{l}0.5 \% \text { potassium nitrate, } 0.11 \% \text { weight }(1100 \mathrm{ppm}) \text { fluoride ion, } 35 \% \\
\text { carbamide peroxide and } 0.25 \% \text { sodium fluoride. Its } \mathrm{pH} \text { is } 6.5\end{array}$ & $\begin{array}{l}\text { Ultra-dent Products, } \\
\text { Utah, USA }\end{array}$ \\
\hline Artificial saliva & $\begin{array}{l}1.72 \mathrm{gm}) \text { hydrous sodium bicarbonate, }(0.468 \mathrm{gm}) \text { sodium hydro phosphate } \\
\text { and }(0.11 \mathrm{gm}) \text { calcium chloride diluted in } 1 \text { liter of distilled water with } \mathrm{pH} 7\end{array}$ & $\begin{array}{l}\text { Faculty of Pharmacy, } \\
\text { Cairo University, Egypt }\end{array}$ \\
\hline
\end{tabular}

\section{Mold fabrication and specimens' preparation:}

A hole $2 \mathrm{~mm}$ in height and $5 \mathrm{~mm}$ in diameter was prepared in the middle of a disc shaped Teflon mold. The mold was split into two halves to facilitate the removal of the specimens. A peripheral metal ring adapted snugly around the mold to prevent displacement of the two halves. The Teflon mold was placed on a clean glass slab covered by a polyester strip. Tetric Ceram piece was packed into the hole using a Teflon instrument. It was covered by a polyester strip and pressed by another glass slab. The excess material was removed by a Teflon instrument. The specimen was polymerized for 40 seconds from both sides of the mold using Cromalux E halogen light curing unit. Its operating voltage is $230 \mathrm{~V}, 50-60 \mathrm{HZ}$. It emitted light having a wavelength ranging from 400 to $540 \mathrm{~nm}$ at light intensity of 650-800 mW/ $\mathrm{cm}^{2}$. For F2000 specimens, the material was injected from the nozzle into the Teflon mold hole. The material was covered by a polyester strip and pressed by a glass slab. It was polymerized using Cromalux E halogen light curing unit for 40 seconds from both sides of the mold. Tetric Ceram and F2000 specimens were placed into separate closed glass containers containing artificial saliva for 24 hours in an incubator at $37^{\circ} \mathrm{C}$.

\section{Pretreatment measurement of surface roughness:}

A Profilometer (surface roughness tester) was used to measure surface roughness (Figure 1). It consists of a display unit, detector tip and calibration stage. It has a maximum measurement up to $350 \mu \mathrm{m}$. It was connected to a personal computer

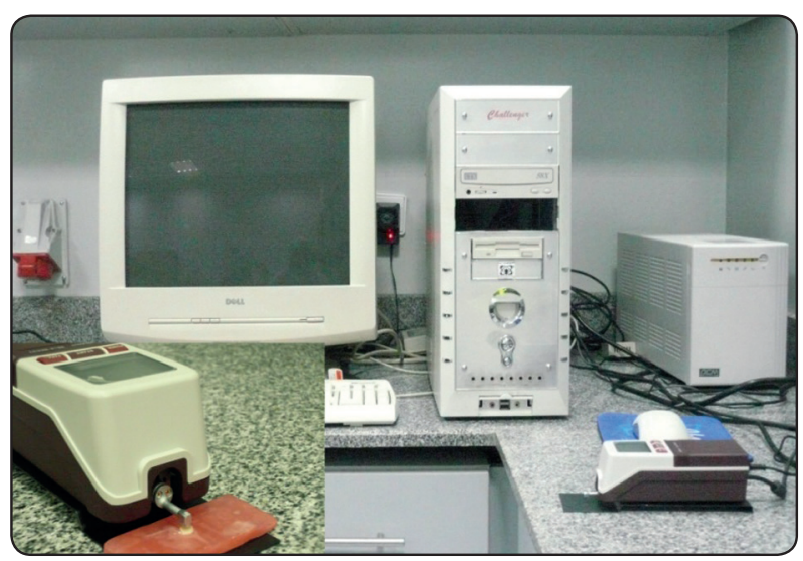

Fig. (1) Surface roughness testing 
which displayed the measurements in micrometers. Each specimen was removed from the artificial saliva with a tweezers and dried then, the specimen was fixed on a block of wax with the top facing the detector unit. The assembly was placed on the calibration stage centralized under the detector unit. Three measurements in vertical, horizontal and oblique directions were taken. The mean of the three readings was recorded as the surface roughness value of the specimen [Ra, um]. After taking the measurement, the specimen was removed from the wax block and washed under running tap water then restored in the container which contained the artificial saliva.

\section{Treatment of the specimens for both materials:}

In control group specimens were stored in artificial saliva, till the end of each treatment period, namely 24 hours, one week or one month. The artificial saliva was changed daily. For second subgroup, each specimen of both materials, hybrid resin composite and compomer were removed from the artificial saliva and plot dried. The specimen was placed into a container having $5 \mathrm{ml}$ of $15 \%$ carbamide peroxide bleaching agent for 6 hours daily throughout different test periods namely 24 hours, one week or one month. For third subgroup, the same procedures were repeated for $35 \%$ carbamide peroxide bleaching agent, however specimens were immersed for 1 hour daily. After removing the specimens from the bleaching agent, they were rinsed under running tap water for 5 minutes. Then they were stored in artificial saliva for the next day.

\section{Post treatment measurement of surface roughness:}

At the end of every treatment period, the specimens were measured for surface roughness following the same way as pretreatment measurement. The change of surface roughness was calculated by subtracting the post treatment measurements from the pretreatment measurements. The data was then collected, tabulated and statistically analyzed.

\section{Statistical analysis:}

One-way Analysis of Variance (ANOVA) was used to test the effect of different bleaching agent concentrations and different time intervals on the surface roughness of Tetric Ceram and F2000. When ANOVA test result was found significant, Tukey's post- hoc test was used to determine the significance of intergroup differences. Student's t-test was used to test the significance of surface roughness differences between the two restorative materials

\section{Micro-morphological study:}

Two specimens out of every test group were randomly selected to be studied by Environmental Scanning Electron Microscope. Scanning electron photomicrographs were taken using LFD (large field detector) at $30 \mathrm{KV}$. Photomicrographs were taken at magnification $1500 \mathrm{X}$, with spot size 50 $\mu \mathrm{m}$ to show the micro morphological changes. Every specimen was removed from the artificial saliva, plot dried and placed inside the microscope chamber with the top of the specimen facing the detector. After five minutes, the photomicrograph at the selected magnification was displayed on the personal computer connected to the microscope.

\section{RESULTS}

\section{Surface roughness changes:}

The data is shown as means and standard deviation (SD) values. The effect of bleaching on surface roughness [Ra, um] of different materials is shown in table 2. ANOVA test (one-way analysis of variance) and Tukey's test revealed statistically significant increase of surface roughness of Tetric Ceram and F2000 following bleaching with $15 \%$ carbamide peroxide and 35\% carbamide peroxide compared to control specimens with no statistical significant differences between the two concentrations at $\mathrm{p}$ value $\leq 0.05$. This was evident after 24 hours and 1 week. After one-month treatment, statistically non-significant difference between the mean surface roughness values of 
Tetric Ceram and F2000 specimens was found whether treated with $15 \%$ carbamide peroxide or $35 \%$ carbamide peroxide, or stored in artificial saliva [control group] at $\mathrm{P}$ value $\leq 0.05$.

The effect of storage time on surface roughness [Ra,um] of different materials is shown in table 3. It revealed a statically significant increase in the mean surface roughness of F2000 and Tetric Ceram on prolonged storage. The mean surface roughness after one month was significantly higher than that after one week which was also significantly higher than that after 24 hours at $\mathrm{P}$ value less than 0.05 . This was evident in bleached groups [15\% or $35 \%$ carbamide peroxide] and control group.

Comparing the mean surface roughness values of both Tetric ceram and F2000 using Student t-test revealed statistically non-significant difference between the surface roughness of both materials. This was shown for control specimens or specimens treated with $15 \%$ carbamide peroxide or $35 \%$ carbamide peroxide at different treatment periods at $\mathrm{p}$ value $\geq 0.05$.

\section{Micro morphological changes:}

Non-bleached Tetric Ceram specimens showed initially slight irregularities [fig. 2a].On increased storage time, more irregularities was evident with appearance of dark spots after one month [fig. 2b]. Following bleaching with either $15 \%$ or $35 \%$ carbamide peroxide, the surface showed more pitting and irregularities compared to control group. The dark spots were more revealed on the whole surface [figure $2 \mathrm{c}, 2 \mathrm{~d}$,]. It was evident that bleaching affected surface morphology of resin composite.

For F2000 non-bleached group, the specimens revealed minute surface irregularities and thin cracks [fig.3a]. The cracks were more evident after one week and one-month storage [fig. 3b]. Following bleaching with $15 \%$ and $35 \%$ carbamide peroxide, the cracks increased in number and become deeper and wider with evidence of surface disintegration. It also showed extensive pitting with granular appearance [fig. 3c, 3d].

TABLE (2): Means and descriptive statistics of mean surface roughness differences (Ra, $\mu \mathrm{m}$ ) of Tetric Ceram and F2000 with different bleaching regimens concentrations using ANOVA test and Tukey's test.

\begin{tabular}{|c|c|c|c|c|c|c|c|c|}
\hline \multirow{2}{*}{ Intervals } & \multirow{2}{*}{$\begin{array}{l}\text { Bleaching } \\
\text { regimen } \\
\text { Material }\end{array}$} & \multicolumn{2}{|c|}{ Control } & \multicolumn{2}{|c|}{$\begin{array}{c}15 \% \text { carbamide } \\
\text { peroxide }\end{array}$} & \multicolumn{2}{|c|}{$\begin{array}{c}35 \% \text { carbamide } \\
\text { peroxide }\end{array}$} & \multirow{2}{*}{ P-value } \\
\hline & & Mean & SD & Mean & SD & Mean & SD & \\
\hline \multirow{2}{*}{24 hours } & Tetric ceram & $0.34^{\mathrm{b}}$ & 0.1 & $0.46^{\mathrm{a}}$ & 0.13 & $0.5^{\mathrm{a}}$ & 0.16 & $0.038 *$ \\
\hline & F2000 & $0.36^{\mathrm{b}}$ & 0.11 & $0.48^{\mathrm{a}}$ & 0.07 & $0.44^{\mathrm{a}}$ & 0.07 & $0.021 *$ \\
\hline \multirow{2}{*}{1 week } & Tetric ceram & $0.51^{\mathrm{b}}$ & 0.12 & $0.73^{a}$ & 0.3 & $0.81^{\mathrm{a}}$ & 0.25 & $0.021 *$ \\
\hline & F2000 & $0.65^{\mathrm{b}}$ & 0.21 & $0.9^{\text {a }}$ & 0.24 & $0.84^{\mathrm{a}}$ & 0.19 & 0.037 * \\
\hline \multirow{2}{*}{1 month } & Tetric ceram & 0.8 & 0.5 & 1.01 & 0.23 & 1.06 & 0.53 & 0.365 \\
\hline & F2000 & 1.08 & 0.27 & 1.33 & 0.58 & 1.1 & 0.2 & 0.307 \\
\hline
\end{tabular}

$* P<0.05=$ Significance, $P>0.05=$ non-significant

Means with different letters are significantly different according to Tukey's test 
TABLE (3): Means and descriptive statistics of mean surface roughness differences in $(\mathrm{Ra}, \mu \mathrm{m})$ of Tetric Ceram and F2000 after different time intervals using ANOVA test and Tukey's test.

\begin{tabular}{|c|c|c|c|c|c|c|c|c|}
\hline \multirow{2}{*}{ Bleaching regimen } & \multirow{2}{*}{$\begin{array}{l}\text { Interval } \\
\text { Material }\end{array}$} & \multicolumn{2}{|c|}{24 hours } & \multicolumn{2}{|c|}{1 week } & \multicolumn{2}{|c|}{1 month } & \multirow{2}{*}{ P-value } \\
\hline & & Mean & SD & Mean & SD & Mean & SD & \\
\hline \multirow[t]{2}{*}{ Control } & Tetric ceram & $0.34^{\mathrm{c}}$ & 0.1 & $0.51^{\mathrm{b}}$ & 0.12 & $0.8^{\mathrm{a}}$ & 0.5 & $0.006 *$ \\
\hline & F2000 & $0.36^{\mathrm{c}}$ & 0.11 & $0.65^{\mathrm{b}}$ & 0.21 & $1.08^{\mathrm{a}}$ & 0.27 & $<0.001 *$ \\
\hline \multirow{2}{*}{$15 \%$ carbamide peroxide } & Tetric ceram & $0.46^{\mathrm{c}}$ & 0.13 & $0.73^{b}$ & 0.3 & $1.01^{\mathrm{a}}$ & 0.23 & $<0.001 *$ \\
\hline & F2000 & $0.48^{\mathrm{c}}$ & 0.07 & $0.9^{\mathrm{b}}$ & 0.24 & $1.33^{\mathrm{a}}$ & 0.58 & $<0.001 *$ \\
\hline \multirow[t]{2}{*}{$35 \%$ carbamide peroxide } & Tetric ceram & $0.5^{\mathrm{b}}$ & 0.16 & $0.81^{\mathrm{a}}$ & 0.25 & $1.06^{\mathrm{a}}$ & 0.53 & $0.005^{*}$ \\
\hline & F2000 & $0.44^{\mathrm{c}}$ & 0.07 & $0.84^{b}$ & 0.19 & $1.1^{\mathrm{a}}$ & 0.2 & $<0.001 *$ \\
\hline
\end{tabular}

*P<0.05=Significant,

P>0.05=non-significant

TABLE (4): Means and descriptive statistics of mean surface roughness differences in (Ra, $\mu \mathrm{m})$ of both restorative materials Tetric Ceram and F2000 using Student's-t test.

\begin{tabular}{|c|c|c|c|c|c|c|}
\hline \multirow{2}{*}{ Bleaching regimen } & \multirow{2}{*}{$\begin{array}{l}\text { Restorative material } \\
\text { Interval }\end{array}$} & \multicolumn{2}{|c|}{ Tetric Ceram } & \multicolumn{2}{|c|}{ F2000 } & \multirow{2}{*}{ P-value } \\
\hline & & Mean & SD & Mean & SD & \\
\hline \multirow{3}{*}{ Control } & 24 hours & 0.34 & 0.1 & 0.36 & 0.11 & 0.901 \\
\hline & 1 week & 0.51 & 0.12 & 0.65 & 0.21 & 0.078 \\
\hline & 1 month & 0.8 & 0.5 & 1.08 & 0.27 & 0.120 \\
\hline \multirow{3}{*}{$15 \%$ carbamide peroxide } & 24 hours & 0.47 & 0.13 & 0.48 & 0.07 & 0.653 \\
\hline & 1 week & 0.73 & 0.3 & 0.9 & 0.24 & 0.179 \\
\hline & 1 month & 1.01 & 0.23 & 1.33 & 0.58 & 0.126 \\
\hline \multirow{3}{*}{$35 \%$ carbamide peroxide } & 24 hours & 0.5 & 0.16 & 0.44 & 0.07 & 0.335 \\
\hline & 1 week & 0.81 & 0.25 & 0.84 & 0.19 & 0.797 \\
\hline & 1 month & 1.06 & 0.53 & 1.1 & 0.2 & 0.817 \\
\hline
\end{tabular}

$* P<0.05=$ Significance,$P>0.05=$ non-significant
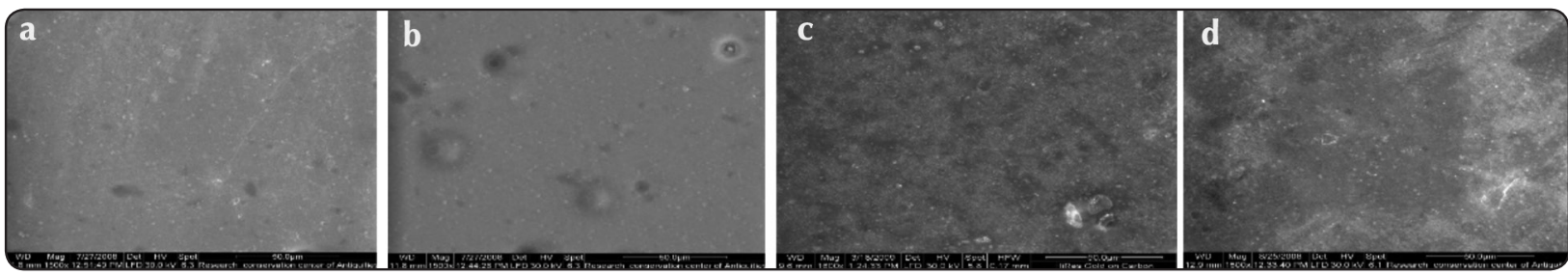

Fig. (2) Scanning Electron micrograph for Tetric Ceram (a) non-bleached after 24 hours, (b) non-bleached after one month (c) bleached with $15 \%$ carbamide peroxide after one week (d) bleached with $35 \%$ carbamide peroxide after one month 

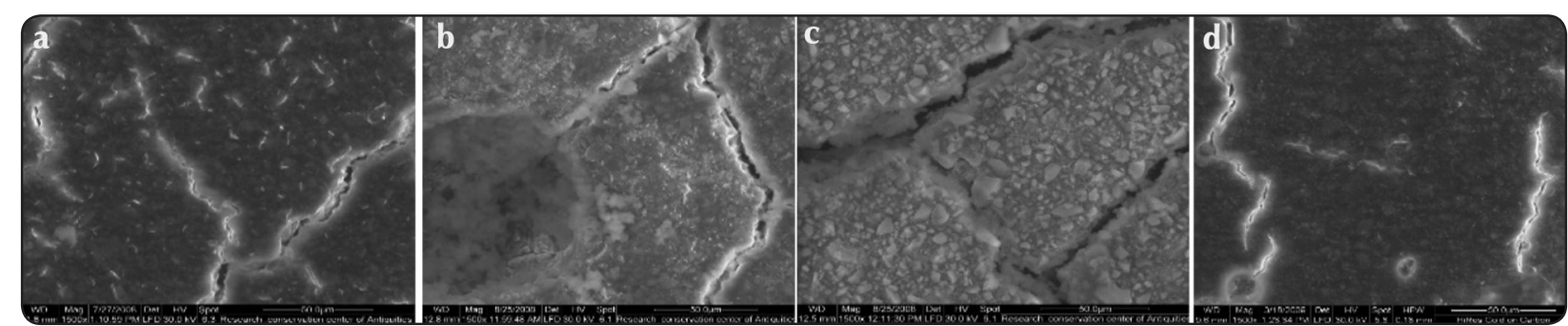

Fig. (3) Scanning Electron micrograph for F2000 (a) non-bleached after 24 hours, (b) non-bleached after one week (c) bleached with $15 \%$ carbamide peroxide after one month (d) bleached with $35 \%$ carbamide peroxide after one month.

\section{DISCUSSION}

In this study two methods of surface topographic evaluations were used. The first was the profilometric surface roughness analysis, which represents a quantitative evaluation of surface roughness. The second method was the Scanning Electron Microscopic (SEM) analysis which represents a qualitative micro morphological evaluation of the restoratives surfaces. Furthermore, the SEM photomicrographs may reveal some surface changes that cannot be easily detected by profilometric surface roughness analysis. The combination of the two methods of analysis might provide more or less an accurate description to the actual surface changes of the restorative materials due to the application of bleaching agents. This was in accordance with Salama $^{(10)}$.

In this study the home bleaching agents used increased the surface roughness of both resin composite and compomer restoratives especially after 24 hours and 1 week (table 2). This could be referred to the effect of carbamide peroxide on the resin matrix of restoratives and the subsequent hydrolysis and chemical erosion of the resin matrix. Chemical erosion of resinous materials is caused by complex interaction of the multicomponent bleaching agents rather than by one specific chemical component. As well as, the softening effect of carbamide peroxide which breaks down into hydrogen peroxide and urea. Hydrogen peroxide breaks down into free radicals, which combine to form molecular oxygen and water. It is believed that this chemical process may accelerate the hydrolytic degradation of compomer and resin composite. This explanation was in agreement with other researchers ${ }^{(11-16)}$. They referred the softening of resin composite restoratives after carbamide peroxide application to the solubility parameters of the resin matrix. Studying the SEM photomicrographs, showed increasing in surface porosity and cracks of Tetric Ceram and F2000 after bleaching which confirmed the previous results. This result was contradicted by Mortazavi et al., ${ }^{(17)}$ and Langesten et $a l^{(18)}$. They found no significant difference between the surface roughness of the bleached resin composite restoratives and that of the control group. This controversy may be related to the difference in the resin composites tested and the difference in the experimental designs (14). Comparing the effect of two concentration of carbamide peroxide on surface roughness revealed that there was no significant difference in the mean surface roughness of the examined restoratives due to the different concentrations either $15 \%$ or $35 \%$ carbamide peroxide (table 2 ). This result was confirmed by the SEM photomicrographs which revealed increased surface roughness of both materials after both bleaching agents. This finding agreed with with Turker and Biskin ${ }^{(19)}$. However, it contradicted with Ayad et al., ${ }^{(16)}$ who found that higher concentrations of carbamide peroxide caused more increase in the surface roughness of resin composite restoratives. 
Considering the effect of storage time on surface roughness, it was found that the surface roughness of Tetric Ceram and F2000 increased by time intervals (table 3). The SEM photomicrographs for Tetric Ceram and F2000 confirmed increased surface roughness with time. This result could be referred to the longer periods of resin composite exposure to the bleaching agents which may provide a longer time for the hydrogen peroxide and the high-energy oxygen free radicals to act on the resin matrix. In addition, the absorption of water and the erosion effect of the bleaching agents, led to expansion and shrinkage between the fillers and the resin matrix of F2000. This might lead to creation of stress corrosion and complete or partial detachment in the matrixfiller interfaces and subsequent crack formation. With further exposure to bleaching agents for longer time, hydrogen peroxide and oxygen free radicals caused further filler matrix debonding and crack propagation that increased the surface roughness of F2000 by time. Also, longer storage time in the control group allowed for hydrolytic degradation of resin composite matrix and further filler-matrix debonding These explanations came in accordance with other researchers ${ }^{(19,20,21)}$

Comparing the surface roughness of both materials revealed that there was no significant difference between surface roughness of Tetric Ceram and F2000 following different bleaching regimens at different time intervals. These findings were in agreement with Wattanapayungkul and $Y{ }^{(22)}$. Comparing the filler content of both material, they both have comparable filler content; Tetric Ceram (60\%) and F2000 (67\%) by volume and both have fluoride releasing filler; Ba-Al-fluorosilicate glass in Tetric Ceram and Fluroalumino silicates in F2000 which are liable for leaching out. In case of water sorption, water might penetrate into filler matrix interface leading to debonding and increasing surface roughness of both materials. Meanwhile, the surface roughness of composite and compomer restoratives might be the result of the interaction of multiple factors such as; filler type, size and distribution as well as the type of resinous matrix and the bond at the filler-matrix interface. These results disagreed with Wattanpayungkul et al. (21) reported that F2000 showed a rougher surface than resin composites. However, in their study, the resin composites utilized was different than that used in the present study.

\section{CONCLUSIONS}

Under the circumstances of this study, it could be concluded that home bleaching agents enhanced the initial changes in surface roughness and topography of hybrid resin composite and compomer esthetic restoratives irrespective of their concentrations. The combination of profilometric and Scanning Electron Microscopic analysis might be considered a reliable method to get accurate results.

\section{REFERENCES}

1- Joiner A. The bleaching of teeth: A review of the Literature. J. Dent. 2006: 34: 412-419.

2- Haywood VB and Heymann HO. Nightguard vital bleaching. Quint. Int. 1989: 20:173-176.

3- Carlos NR, Bridi EC, Amaral FLB, et al. Efficacy of Home-use Bleaching Agents Delivered in Customized or Prefilled Disposable Trays: A Randomized Clinical Trial. Oper. Dent. 2017: 42:30-40.

4- Greenwall L, Fredman G, Gordan VV. Bleaching Techniques in Restorative Dentistry: An Illustrated Guide. London: Martin Dunitz Ltd., 2001.

5- Alonso PV\& Lopez RM. Randomized clinical trial on the efficacy and safety of four professional at-home tooth whitening gels. Oper. Dent. 2014: 39:136-143.

6- Tredwin CJ, Naik S, Lewis NJ, Scully C. Hydrogen peroxide toothwhitening (bleaching) products: Review of adverse effects and safety issues. Br Dent J 2006; 200: 371376 .

7- Basting RT, Fernandez CF, Ambrosano GM, and Campos I. Effect of $10 \%$ carbamide peroxide bleaching agent on roughness and micro hardness of packable composite resins. J. Esthet. Rest. Dent. 2005:17: 256-263. 
8- Gurgan S and Yalcin F. The effect of two different bleaching regimens on the surface roughness and hardness of tooth colored restorative materials. Quint. Int. 2007:38: 83-87.

9- Hanning C, Duong S, Becker K, Brunner E, Kahler E and Attin T. Effect of bleaching on subsurface micro-hardness of composite and polyacid modified composite. Dent. Mater. 2007: 23: 198-203.

10- Salama FS. Effect of home bleaching agent on the texture and surface roughness of glass ionomer and compomer restorative material. Saudi Dent. J. 2001: 13: 66-70,

11- Cengiz E, kurtulmus-YS, Ulusoy N, deniz ST, and devrim EY. The Effect of Home Bleaching Agents on the Surface Roughness of Five Different Composite Resins: A SEM Evaluation Wiley Periodicals, Inc. SCANNING VOL. 2016: 38:277-283.

12- Gül P, Harorli OT, Akgül1 N, Gündoğdu3 M. Effect of Different Bleaching Applications on the Surface Properties and Staining susceptibility of Dental Composites Journal of Wuhan University of Technology-Mater. Sci. Ed. (www. jwutms.net) June 2016: 677- 683 .

13- Rosentritt M, Lang R, Plein T, Behr M and Handel G. Discoloration of restorative materials after bleaching application. Quint. Int. 2005: 36: 33-39.

14- Attin T, Hannig C, Wiegand A, and Attin R. Effect of bleaching on restorative materials and restorations - a systematic review. Dent. Mater. 2004:20: 852-861.

15- Cehreli ZC, Yazici R and Garcia- Godoy F. Effect of home use bleaching gels on fluoride releasing restorative materials. Oper. Dent. 2003: 28: 605-609.

16- Ayad NM, Bedewi AE, Hanafy SA, and Saka SE. Effect of bleaching on microleakage, surface hardness, surface roughness and color changes of an ormocer and a conventional hybrid resin composite. J. Dent. Sc. 2009: 6:1-15.

17- Mortzavi V, Fathi MH, and Shirian MR. Effect of bleaching on surface roughness of two nanofilled and microhybrid composite. J. Isfahan Dental School, Isfahan University of Medical Sciences; 2009:3:195-205.

18- Langsten RE, Dunn WJ, Hartup GR and Murchinson DF. Higher concentration carbamide peroxide effects on surface roughness of composites. J. Esthet. Rest. Dent. 2002:14: 92-96.

19- Turker SB and Biskin T. Effect of three bleaching agents on the surface properties of three different esthetic restorative materials. J. Prosth. Dent. 2003:89:466-473.

20- Polydorou O, Hellwig E and Auschill TM. The effect of different bleaching agents on the surface texture of restorative materials. Oper. Dent. 2006: 31: 473-480.

21- Wattanapayungkul P, Yap AUJ, Chooi KW, Lee MFLA, Selamat RS and Zhou RD. The effect of home bleaching agents on the surface roughness of tooth colored restoratives with time. Oper. Dent. 2004: 29: 398-403.

22- Wattanapayungkul P and Yap AUJ. Effects of in office bleaching products on surface finish of tooth colored restorations. Oper. Dent. 2003: 28: 15-19. 